\title{
PENGEMBANGAN E-LEARNING MENGGUNAKAN PORTAL PEMBELAJARAN MAHASISWA PADA MATA KULIAH KONSEP DASAR IPA 2 DI ERA DISRUPTION
}

\author{
Kharisma Eka Putri ${ }^{1}$ dan Susi Damayanti ${ }^{2}$. \\ kharismaputri@unpkediri.ac.id ${ }^{1}$, susidamayanti@unpkediri.ac.id ${ }^{2}$ \\ PGSD, FKIP, UN PGRI Kediri ${ }^{12}$
}

\begin{abstract}
Abstrak: Dalam dunia pendidikan saat ini juga harus dirubah sesuai dengan perkembangan ilmu pengetahuan dan teknologi misalnya dalam bentuk pembelajaran $E$ learning. Karena dengan E-learning penyampaian muatan informasi tidak hanya menjadi tujuan pendidikan, akan tetapi dengan media E-learning kegiatan pembelajaran dapat dilakukan dimanapun kapan pun tanpa dibatasi oleh ruang dan waktu. Namun kenyataan di lapangan, pada mata kuliah konsep dasar IPA 2 mahasiswa melakukan kegiatan belajar hanya di dalam ruang kelas dengan waktu yang cukup lama dan dengan aktivitas yang sama. Sehingga mahasiswa cenderung bosan. Berdasarkan paparan tersebut, tujuan penelitian ini adalah untuk mengembangkan E-learning yang valid, praktis dan efektif menggunakan portal pembelajaran mahasiswa pada mata kuliah konsep dasar IPA 2 di era disruption. Model penelitian pengembangan yang digunakan dalam penelitian pengembangan ini adalah modifikasi model Borg \& Gall dan Lee \& Owen dengan tahapan penelitian dan pengumpulan data, perencanaan, pengembangan produk, validasi desain, revisi desain, uji coba produk, revisi produk, dan uji coba pemakaian. Berdasarkan hasil uji coba produk, media E-learning menggunakan portal pembelajaran mahasiswa pada mata kuliah konsep dasar IPA 2 di era disruption menurut ahli materi memperoleh skor prosentase validitas sebesar $88 \%$, ahli media $89 \%$, dan ahli bahasa $86 \%$ dengan kategori valid. Berdasarkan respon kepraktisan mahasiswa, produk ini memperoleh skor $80 \%$ berdasarkan respon kepraktisan pengguna mempeoleh skor $90 \%$ dengan kategori praktis. Sedangkan untuk keefektifan produk ini mencapai $80 \%$ dengan kategori efektif. Berdasarkan data tersebut dapat disimpulkan bahwa media E-learning valid, praktis, dan efektif. Sehingga media E-learning menggunakan portal pembelajaran mahasiswa pada mata kuliah konsep dasar IPA 2 di era disruption layak untuk digunakan.
\end{abstract}

Kata kunci: e-learning, portal pembelajaran mahasiswa, konsep dasar IPA 2, disruption 


\title{
Kharisma, Susi, Pengembangan Elearning Menggunakan Portal... DEVELOPMENT OF E-LEARNING USING STUDENT LEARNING PORTAL ON COURSES OF SCIENCE BASIC CONCEPT 2 IN THE DISRUPTION ERA
}

\begin{abstract}
In the world of education today must also be changed according to the development of science and technology for example in the E-learning education. Because with E-learning the delivery of information content is not only an educational goal, but with media E-learning, learning activities can be done anywhere at any time without being limited by space and time. But in the reality, on the courses of science basic concept 2 , students conduct learning activities only in classrooms with considerable time and with the same activities. So that students tend to be bored. Based on these explanations, the purpose of this study was to develop E-learning (valid, practice and effective) using student learning portals in the science basic concepts 2 in the disruption era. The type model of development research in this development research is the modification of the Borg \& Gall and Lee \& Owen models with the stages of research and data collection, planning, product development, design validation, design revision, product testing, product revision, and usage testing . Based on the results of product testing, E-learning media using student learning portals on the courses of science basic consep 2 in the disruption era according to substance experts obtained a percentage validity score of $88 \%$, $89 \%$ media experts, and $86 \%$ linguists with valid categories. Based on students' practicality response, this product obtained a score of $80 \%$ based on the user's practicality score of $90 \%$. While the effectiveness of this product reaches $80 \%$ in the effective category. Based on these data it can be concluded that E-learning media is valid, practical, and effective. So that E-learning media using the student learning portal in the courses science basic concept 2 in the disruption era is feasible to use.
\end{abstract}

Keywords: e-learning, student learning portal, science basic concept 2, disruption

\section{PENDAHULUAN}

Saat ini dunia sedang menghadapi fenomena disruption (disrupsi), dimana pergerakan dunia industri atau persaingan kerja tidak lagi linear. Perubahan yang terjadi sangat cepat, fundamental dengan merubah pola tatanan lama untuk menciptakan tatanan baru. Perubahan yang sangat luas mulai dari dunia bisnis, perbankan, transportasi, sosial masyarakat, hingga pendidikan. (Kasali, 2017), menjelaskan di era ini akan menuntut kita untuk berubah atau punah. Pendidikan harus juga dirubah misalnya dengan hadir dalam bentuk E-learning. Karena dengan E-learning penyampaian muatan informasi tidak hanya menjadi tujuan pendidikan, akan tetapi lebih memperhatikan bagaimana cara 
Kharisma, Susi, Pengembangan E-learning Menggunakan Portal... membangun karakter peserta didik, bahkan termasuk cara-cara berpikir kreatif. Serta dengan media E-learning kegiatan pembelajaran dapat dilakukan dimanapun kapan pun tanpa dibatasi oleh ruang dan waktu.

Namun pada kenyataannya hasil observasi diperoleh pembelajaran yang dilakukan terutama pembelajaran pada mata kuliah konsep dasar IPA 2 di era disruption masih dilakukan secara konvensional dan ada pula yang menggunakan media tetapi media yang digunakan hanya media power point saja. Dari hasil survei lapangan $31 \%$ menggunakan metode ceramah tanpa media, 51\% menggunakan media power point, dan $18 \%$ menggunakan media lainnya. Padahal dari hasil wawancara dengan mahasiswa, jika pembelajaran menggunakan metode ceramah ataupun menggunaan media power point pembelajaran dirasa kurang efektif, karena mahasiswa cenderung bosan dan melakukan kegiatan lain diluar kegiatan pembelajaran, selain itu sebab lainnya adalah mahasiswa dituntut untuk melakukan kegiatan belajar di dalam ruang kelas dengan waktu yang cukup lama hanya dengan aktivitas yang sama.

Dari paparan tersebut, perlu adanya pengembangan media pembelajaran yang membuat mahasiswa lebih tertarik untuk melakukan proses pembelajaran pada mata kuliah konsep dasar IPA 2 di era disruption agar mahasiswa tidak merasa bosan, dengan melakukan aktivitas yang tidak monoton, kegiatan pembelajaran juga bisa dilakukan diluar kelas tanpa dibatasi oleh ruang dan waktu. Salah satu media pembelajaran yang dapat mengatasi permasalahan yang ada adalah media pembelajaran E-learning. Menurut (Khan, 2005) E-learning menunjuk pada pengiriman materi pembelajaran kepada siapapun, dimanapun, dan kapanpun dengan menggunakan berbagai teknologi dalam lingkungan pembelajaran yang terbuka, fleksibel, dan terdistribusi. Media E-learning merupakan bentuk pendidikan jarak jauh yang menggunakan media elektronik sebagai media penyampaian materi dan komunikasi antara pengajar dengan pelajarnya. $E$ learning merupakan media pembelajaran yang interaktif, di dalam sistem ini bisa dilakukan diskusi secara online, melakukan pembelajaran secara online, mengerjakan soal beserta pembahasan, melihat nilai secara langsung dan masih banyak lagi.

Berdasarkan latar belakang tersebut, peneliti mengambil judul “pengembangan $E$ learning menggunakan portal pembelajaran mahasiswa pada mata kuliah konsep dasar IPA 2 di era disruption." 
Kharisma, Susi, Pengembangan E-learning Menggunakan Portal... METODE

Penelitian ini menggunakan model penelitian pengembangan yaitu modifikasi model Borg \& Gall dan Lee \& Owen (2004). Kedua model tersebut dimodifikasi untuk saling melengkapi keterbatasan dan mengoptimalkan kelebihan dari masing-masing model. Di mana Model Borg \& Gall fokus kepada kegiatan penelitian, sedangkan untuk model Lee \& Owen fokus kepada kegiatan pengembangan medianya. Dengan langkah utama yaitu :

1. Tahapan penelitian dan pengumpulan informasi, adalah tahapan yang berisi analisis kebutuhan dan Front-end analysis.

2. Perencanaan yaitu berisi mengenai pembuatan jadwal, kerja tim, spesifikasi media, struktur isi, dan control konfigurasi.

3. Pengembangan produk yaitu berisi penyusunan kerangka kerja dan membuat media yang sudah direncanakan sebelumnya.

4. Validasi desain yaitu melakukan validasi media E-learning oleh tiga ahli yaitu ahli media, ahli materi dan ahli bahasa.

5. Revisi desain yaitu dari hasil validasi yang telah dilakukan oleh para ahli diperoleh masukan, saran atau kritik kemudian direvisi.

6. Uji coba produk yaitu dilakukan uji coba terbatas terhadap 6 mahasiswa.

7. Revisi produk yaitu melakukan revisi dari hasil uji coba terbatas berdasarkan angket yang sudah diberikan kepada 6 mahasiswa.

8. Uji coba pemakaian yaitu bisa disebut uji lapangan yang diberikan kepada 20 mahasiswa.

Penelitian ini menggunakan teknik analisis data deskriptif kuantitatif dan analisis data deskriptif kualitatif. Analisis deskriptif kuantitatif digunakan sebagai mengolah data yang berasal dari angket dan lembar tes sedangkan analisis deskriptif kualitatif digunakan sebagai pengolah data berupa respon berupa saran, tanggapan, atau kritik. Kemudian untuk data deskriptif kuantitatif dan deskriptif kualitatif dapat diperoleh dari tiga jenis data, yaitu data validitas, kepraktisan, dan keefektifan. Sehingga media dikatakan layak digunakan jika media dinyatakan valid, praktis dan efektif. Media dikatakan valid apabila hasil validasi berupa lembar validasi dari ketiga validator (ahli media, ahli materi, dan ahli bahasa) menyatakan valid dan media dapat digunakan. Kisi-kisi lembar validasi untuk ahli media terdiri dari kecepatan dan kelancaran sistem, dapat diakses di semua 
Kharisma, Susi, Pengembangan E-learning Menggunakan Portal... jenis operating system dan berbagai spesifikasi hardware, alur penggunaan mudah, interaksi dengan media, kreatifitas, dan tampilan. Kisi-kisi lembar validasi untuk ahli materi terdiri dari kelengkapan materi, penyajian materi, kejelasan materi, kemenarikan materi, kesesuaian konsep dan teori, bahasa yang digunakan dalam materi, ketepatan istilah dan pernyataan yang digunakan. Serta kisi-kisi lembar validasi untuk ahli bahasa terdiri dari penggunaan bahasa, kalimat dalam sistem, ketepatan penulisan tanda baca, ketepatan istilah asing yang digunakan, dan ketepatan penggunaan ejakan dan istilah dalam system. Media dikatakan praktis apabila respon pengguna (dosen) dan mahasiswa merespon positif terhadap kegiatan perkuliahan, mengetahui respon pengguna (dosen) dan mahasiswa menggunakan angket. Dan media dikatakan efektif apabila dalam kegiatan perkuliahan hasil belajar yang diperoleh mahasiswa telah mencapai di atas kriteria ketuntasan minimal dan ketuntasan klasikal.

\section{HASIL}

\section{Spesifikasi Produk Yang Dihasilkan}

Luaran hasil yang diperoleh dari penelitian pengembangan ini adalah media $E$ learning menggunakan portal pembelajaran mahasiswa pada mata kuliah konsep dasar IPA 2 di era disruption ini dapat di lihat di laman kharismahasyim.web.id dan selanjutnya diujicobakan pada beberapa subjek yaitu ahli media, ahli materi, ahli bahasa, pengguna (dosen pengguna media) dan mahasiswa yang menempuh mata kuliah konsep dasar IPA 2 di era disruption. Spesifik media E-learning menggunakan portal pembelajaran ini terdiri dari laman depan yang menyajikan username dan password, dan mahasiswa mempunyai akun masing-masing yang terhubung dengan dosen dan mahasiswa lain sehingga akun bersifat privasi, kemudian setelah login mahasiswa dapat memilih mata kuliah yang disajikan "konsep dasar IPA 2", selanjutnya mahasiswa memilih materi yang telah ditentukan dosen yaitu "Tubuh Manusia (Rangka, Sendi, dan Jenis Penyakit Tulang)", dan di dalam menu tersebut terdapat berbagai menu-menu lagi yang terdiri dari Handout (berisi materi), LKM (Lembar Kegiatan Mahasiswa), power point (materi dari dosen), soal (pree test dan post test), vasilitas chating untuk tanya jawab dengan dosen serta mahasiswa lain sehingga perkuliahan dapat dilakukan dimanapun dan kapanpun tidak terbatas oleh waktu dan ruang. 
Kharisma, Susi, Pengembangan E-learning Menggunakan Portal...

\section{Gambar 1. Tampilan Pembuka Produk}

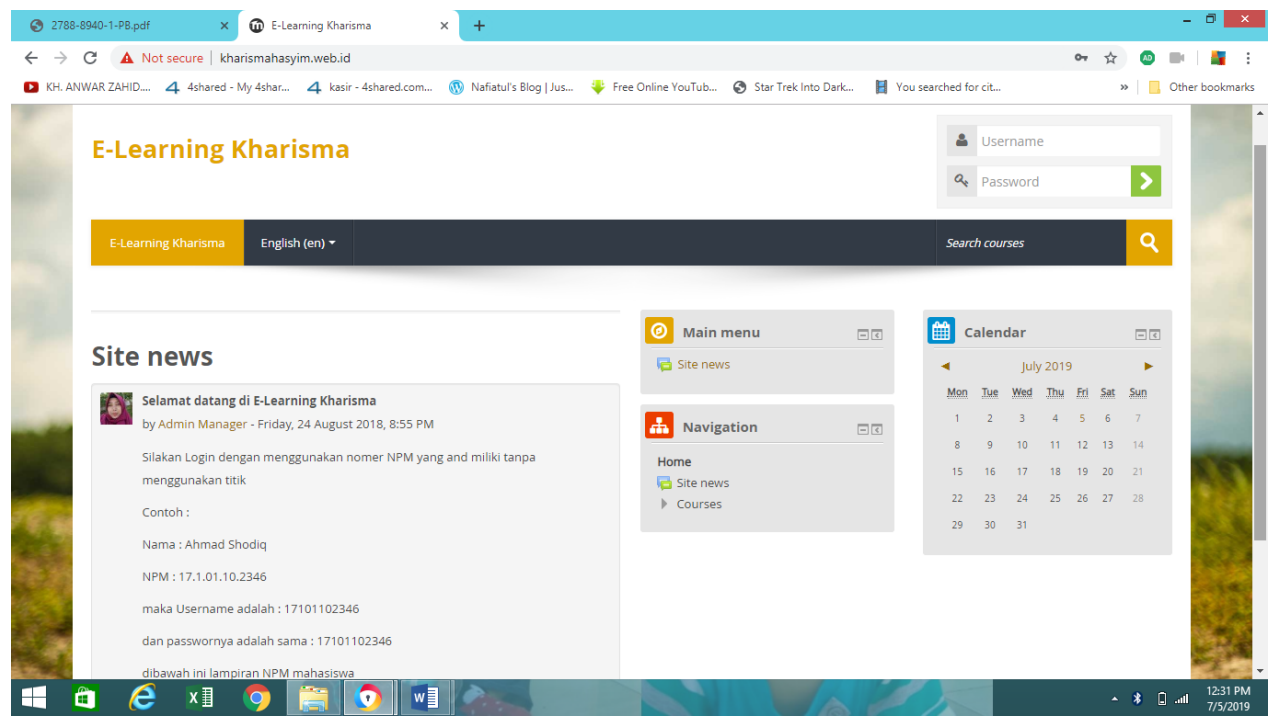

Gambar 2. Tampilan Menu Utama

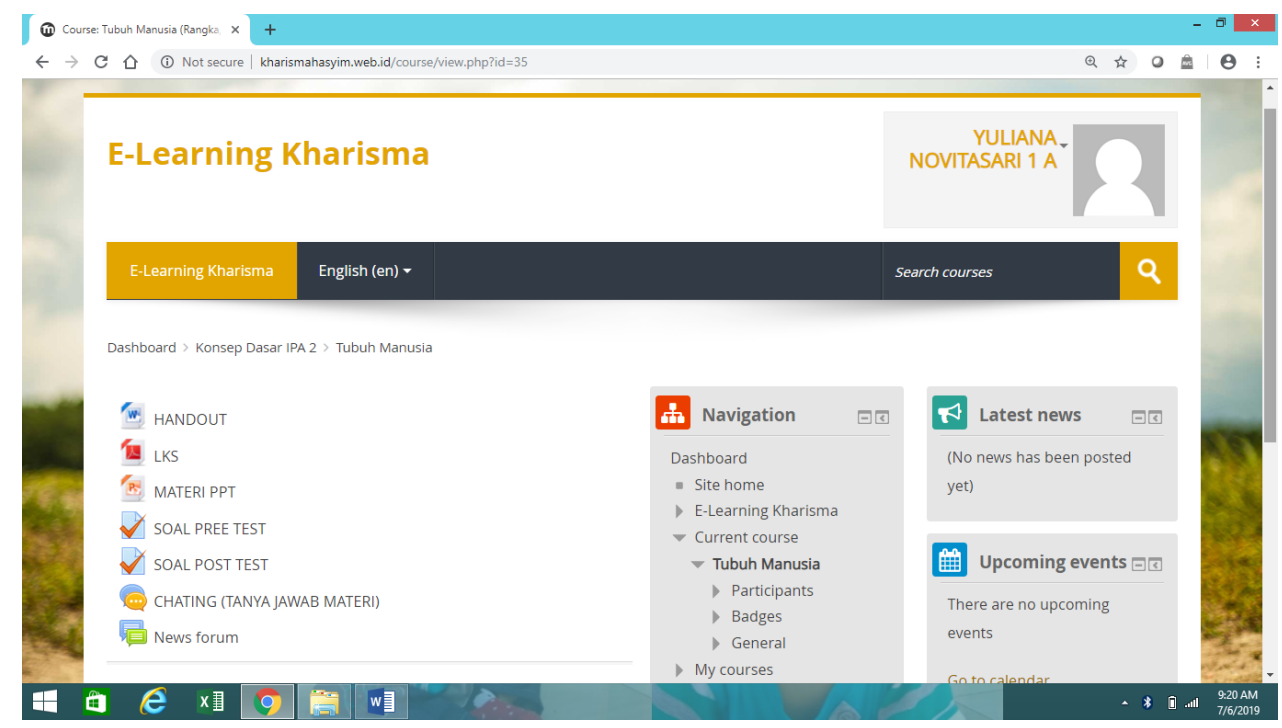

\section{Hasil Validasi Media}

Untuk mengetahui hasil validasi media E-learning menggunakan portal pembelajaran mahasiswa pada mata kuliah konsep dasar IPA 2 di era disruption yang dikembangkan, dilakukan validasi oleh 3 validator, yakni validator ahli media, ahli materi, dan ahli bahasa. Proses validasi yang pertama kali dilakukan oleh ahli media yaitu bapak Sutrisno Sahari, M.Pd. Adapun hasil validasi dari ahli media dapat dilihat pada Table 1. 
Kharisma, Susi, Pengembangan E-learning Menggunakan Portal...

Tabel 1. Hasil Validasi Ahli Media

\begin{tabular}{|c|l|c|c|}
\hline No & \multicolumn{1}{|c|}{ Indikator } & X & Y \\
\hline 1 & Media e-learning tidak berjalan lambat. & 4 & 5 \\
\hline 2 & Media e-learning tidak berhenti (hang) saat pengoprasian. & 4 & 5 \\
\hline 3 & $\begin{array}{l}\text { Media } \text { e-learning dapat dijalankan di semua jenis operating } \\
\text { sistem. }\end{array}$ & 5 & 5 \\
\hline 4 & $\begin{array}{l}\text { Media } \text { e-learning dapat dijalankan di berbagai spesifikasi } \\
\text { hardware. }\end{array}$ & 5 & 5 \\
\hline 5 & System mudah dijalankan. & 5 & 5 \\
\hline 6 & Memilki alur penggunaan media yang jelas. & 4 & 5 \\
\hline 7 & Pengoprasian media yang sederhana. & 4 & 5 \\
\hline 8 & Pengguna dapat berinteraksi dengan media. & 5 & 5 \\
\hline 9 & Kreatif dalam menuangkan ide gagasan. & 4 & 5 \\
\hline 10 & Tampilan menarik. & 4 & 5 \\
\hline 11 & Tulisan dapat dibaca dengan baik. & 5 & 5 \\
\hline & & 49 & 55 \\
\hline
\end{tabular}

Dengan : $\mathrm{X}=$ Skor yang diperoleh, $\mathrm{Y}=$ Skor maksimum

Berdasarkan Tabel 1 menunjukkan bahwa jumlah skor hasil validasi ahli media pengembangan E-learning menggunakan portal pembelajaran mahasiswa pada mata kuliah konsep dasar IPA 2 di era disruption adalah sebesar 49 atau 89\%. Skor tersebut berarti bahwa bahan media tersebut memenuhi kriteria sangat valid dan tidak perlu revisi, sehingga dapat langsung digunakan dalam proses pembelajaran.

Sementara itu, validasi ahli materi mengenai konsep dasar IPA 2 dilakukan oleh Faridha Nurlaila unaidah, M.Pd. Hasil validasi dari ahli materi dapat dilihat pada Tabel 2.

\section{Tabel 2. Hasil Validasi Ahli Materi}

\begin{tabular}{|c|l|c|c|}
\hline No & \multicolumn{1}{|c|}{ Indikator } & X & Y \\
\hline 1 & Materi yang dibahas dalam media lengkap. & 5 & 5 \\
\hline 2 & Materi yang disajikan sistematis. & 5 & 5 \\
\hline 3 & Materi yang disajikan jelas. & 5 & 5 \\
\hline 4 & Materi yang disampaikan dikemas secara menarik. & 4 & 5 \\
\hline 5 & Soal dirumuskan dengan jelas. & 4 & 5 \\
\hline 6 & Soal di dalam media lengkap. & 4 & 5 \\
\hline 7 & Soal sesuai dengan konsep dan teori. & 4 & 5 \\
\hline 8 & Kunci jawaban sesuai dengan soal. & 5 & 5 \\
\hline 9 & Bahasa yang digunakan komunikatif. & 4 & 5 \\
\hline 10 & Istilah dan pertanyaan yang digunakan tepat dan sesuai. & 4 & 5 \\
\hline & JUMLAH & 44 & 50 \\
\hline
\end{tabular}

Dengan : $\mathrm{X}=$ Skor yang diperoleh, $\mathrm{Y}=$ Skor maksimum 
Kharisma, Susi, Pengembangan E-learning Menggunakan Portal...

Tabel 2 menunjukkan bahwa jumlah skor hasil validasi ahli materi konsep dasar IPA 2 adalah sebesar 44 atau $88 \%$. Hal ini berarti bahwa materi pada pengembangan $E$ learning menggunakan portal pembelajaran mahasiswa pada mata kuliah konsep dasar IPA 2 di era disruption sudah memenuhi kriteria sangat valid dan tidak perlu revisi. Kemudian media tersebut akan digunakan untuk uji coba skala terbatas.

Sedangkan validasi ahli bahasa untuk pengembangan E-learning menggunakan portal pembelajaran mahasiswa pada mata kuliah konsep dasar IPA 2 di era disruption dilakukan oleh Rian Damariswara M.Pd. Adapun hasil validasi ahli bahasa sebagaimana Tabel 3.

Tabel 3. Hasil Validasi Ahli Bahasa

\begin{tabular}{|c|l|c|c|}
\hline No & \multicolumn{1}{|c|}{ Indikator } & X & Y \\
\hline 1 & Bahasa yang digunakan dalam system -learning mudah difahami. & 4 & 5 \\
\hline 2 & Kalimat dalam sistem e-learning ringkas tapi padat. & 4 & 5 \\
\hline 3 & Tidak ada penafsiran ganda yang digunakan. & 5 & 5 \\
\hline 4 & $\begin{array}{l}\text { Kesesuaian bahasa yang digunakan dengan kemampuan berbahasa } \\
\text { mahasiswa. }\end{array}$ & 5 & 5 \\
\hline 5 & Bahasa yang digunakan mudah difahami oleh mahasiswa. & 5 & 5 \\
\hline 6 & Ketepatan penulisan tanda baca & 4 & 5 \\
\hline 7 & Istilah asing digunakan secara tepat. & 4 & 5 \\
\hline 8 & Ketepatan penggunaan bahasa yang baik dan tepat. & 4 & 5 \\
\hline 9 & Ketepatan menggunakan bahasa yang baik dan benar. & 4 & 5 \\
\hline 10 & Ketepatan penggunaan ejakan dan istilah. & 4 & 5 \\
\hline & & 43 & 50 \\
\hline
\end{tabular}

Dari Tabel 3 terlihat bahwa jumlah skor hasil validasi ahli bahasa untuk pengembangan E-learning menggunakan portal pembelajaran mahasiswa pada mata kuliah konsep dasar IPA 2 di era disruption adalah sebesar 43 atau 86\%. Hal ini berarti bahwa bahan ajar yang dikembangkan sudah memenuhi kriteria valid dan perlu sedikit revisi dari aspek bahasa. Validator memberikan saran agar kata dan kalimat yang digunakan harus mengacu pada aturan dan kaidah bahasa Indonesia yang baik dan benar.

\section{Hasil Uji Kepraktisan Media}

Kepraktisan bahan ajar yang dikembangkan dinilai berdasarkan respon mahasiswa dan penilaian pengguna terhadap proses pembelajaran dengan menggunakan pengembangan E-learning menggunakan portal pembelajaran mahasiswa pada mata kuliah konsep dasar IPA 2 di era disruption. Adapun data hasil respon mahasiswa dan 
Kharisma, Susi, Pengembangan E-learning Menggunakan Portal... penilaian pengguna terhadap penggunaan media E-learning tersebut adalah sebagai berikut:

\section{Uji Coba Produk Terbatas (Kelompok Kecil)}

Uji coba kelompok kecil ini dilakukan setelah media E-learning menggunakan portal pembelajaran mahasiswa pada mata kuliah konsep dasar IPA 2 di era disruption selesai divalidasi dan direvisi berdasarkan saran dan masukan dari para validator ahli media, ahli materi, dan ahli bahasa. Uji coba kelompok kecil ini akan dilihat kepraktisan awal dalam penggunaan media E-learning menggunakan portal pembelajaran mahasiswa pada mata kuliah konsep dasar IPA 2 di era disruption. Instrumen yang digunakan untuk mangambil data kelayakan media ini berupa angket yang diberikan pada subjek kelompok kecil. Subjek kelompok kecil yang digunakan adalah 6 Mahasiswa PGSD Tingkat 1 yang menempuh mata kuliah konsep dasar IPA 2 semester genap tahun ajaran 2018/2019.

Tahap kepraktisan pada uji coba terbatas ini berdasarkan respon mahasiswa yang menilai aspek grafis dan aspek isi. Hasil angket uji coba terbatas dapat dilihat pada Tabel 4.

Tabel 4. Hasil Respon Mahasiswa Terhadap Produk

\begin{tabular}{|c|l|c|}
\hline No & \multicolumn{1}{|c|}{ Nama Mahasiswa } & Skor \\
\hline 1 & UBAIDILLAH CANDRA PUTRA & 48 \\
\hline 2 & NURMA FITRI HANDAYANI & 41 \\
\hline 3 & ENDAH PURWATI & 45 \\
\hline 4 & TERA NOVIANTININGTYAS R S & 41 \\
\hline 5 & SITI NUR AISYAH & 44 \\
\hline 6 & RENI OKTAFIANA & 47 \\
\hline \multicolumn{2}{|}{ Rata-rata } & 44 \\
\hline
\end{tabular}

Berdasarkan Tabel 4 terlihat bahwa skor rata-rata respon mahasiswa terhadap penggunaan media E-learning menggunakan portal pembelajaran mahasiswa pada mata kuliah konsep dasar IPA 2 di era disruption pada tahap uji coba kelompok kecil adalah sebesar 44 atau $80 \%$. Skor tersebut termasuk dalam kategori sangat baik, sehingga media tersebut praktis digunakan dalam proses perkuliahan.

\section{Data Uji Coba Produk (Lapangan)}

Uji coba selanjutnya yaitu uji coba lapangan yang dilakukan dengan meminta tanggapan responden dari pengguna dan 20 mahasiswa. Pengujian ini merupakan pengujian tahap akhir kategori kepraktisan media yang dikembangkan. Berikut paparan 
Kharisma, Susi, Pengembangan E-learning Menggunakan Portal...

respon pengguna dan mahasiswa terhadap penggunaan media E-learning menggunakan portal pembelajaran mahasiswa pada mata kuliah konsep dasar IPA 2 di era disruption.

\section{Respon pengguna terhadap penggunaan media}

Adapun data hasil angket respon pengguna terhadap penggunaan media $E$ learning menggunakan portal pembelajaran mahasiswa pada mata kuliah konsep dasar IPA 2 di era disruption adalah sebagaimana Tabel 5 berikut:

Tabel 5. Hasil Respon Pengguna Terkait Kepraktisan Produk

\begin{tabular}{|c|l|c|c|}
\hline No & \multicolumn{1}{|c|}{ Indikator } & X & Y \\
\hline 1 & Media -learning tidak berjalan lambat. & 4 & 5 \\
\hline 2 & Media e-learning tidak berhenti (hang) saat pengoprasian. & 4 & 5 \\
\hline 3 & Media e-learning dapat dijalankan di semua jenis operating sIstem. & 4 & 5 \\
\hline 4 & Media e-learning dapat dijalankan di berbagai spesifikasi hardware. & 4 & 5 \\
\hline 5 & Media mudah dijalankan. & 5 & 5 \\
\hline 6 & Memilki alur penggunaan aplikasi yang jelas. & 4 & 5 \\
\hline 7 & Pengoprasian aplikasi yang sederhana. & 5 & 5 \\
\hline 8 & Pengguna dapat berinteraksi dengan media. & 5 & 5 \\
\hline 9 & Kreatif dalam menuangkan ide gagasan. & 5 & 5 \\
\hline 10 & Tulisan dapat dibaca dengan baik. & 5 & 5 \\
\hline 11 & Pemilihan warna sudah tepat. & 4 & 5 \\
\hline 12 & Materi yang disajikan jelas. & 5 & 5 \\
\hline 13 & Pembahasan contoh dalam materi jelas & 4 & 5 \\
\hline 14 & Soal dirumuskan dengan jelas. & 5 & 5 \\
\hline 15 & Soal benar secara teori dan konsep. & 5 & 5 \\
\hline 16 & Kunci jawaban sesuai dengan soal. & 5 & 5 \\
\hline 17 & Bahasa yang digunakan komunikatif. & 4 & 5 \\
\hline 18 & Materi yang disajikan dapat memotivasi mahasiswa untuk belajar. & 4 & 5 \\
\hline 19 & Tampilan yang digunakan menarik. & 5 & 5 \\
\hline 20 & Tulisan dapat dibaca dengan baik. & 4 & 5 \\
\hline JUMLAH & 90 & 100 \\
\hline
\end{tabular}

Dengan : $\mathrm{X}=$ Skor yang diperoleh, $\mathrm{Y}=$ Skor maksimum

Dari Tabel 5 terlihat bahwa jumlah skor angket respon pengguna sebesar 90 atau 90\%. Hal ini berarti bahwa tingkat kepraktisan media E-learning menggunakan portal pembelajaran mahasiswa pada mata kuliah konsep dasar IPA 2 di era disruption berdasarkan respon pengguna mencapai $90 \%$ dengan kategori sangat praktis.

Respon mahasiswa terhadap penggunaan media E-learning menggunakan portal pembelajaran mahasiswa pada mata kuliah konsep dasar IPA 2 di era disruption

Data kepraktisan angket mahasiswa disusun berdasarkan 11 indikator, yaitu (1) kemudahan akses, (2) kejelasan petunjuk, (3) kelancaran saat pengoprasian, (4) 
Kharisma, Susi, Pengembangan E-learning Menggunakan Portal...

kelancaran dalam akses handphon, (5) kejelasan materi, (6) keruntutan materi, (7) bahasa yang komunikatif, (8) media dapat menumbuhkan motivasi, (9) kemudahan soal, (10) tampilan media, (11) ukuran dan tampilan huruf. Berikut hasil respon mahasiswa terhadap kepraktisan media dapat dilihat pada Table 6.

Tabel 6. Hasil Respon Mahasiswa Terkait Kepraktisan Produk

\begin{tabular}{|c|l|c|}
\hline No & \multicolumn{1}{|c|}{ Nama Mahasiswa } & Skor \\
\hline 1 & DWI NOVIA RACHMAWATI & 51 \\
\hline 2 & YULIANA NOVITASARI & 47 \\
\hline 3 & BELLA MEGA SANTOSO PUTRI & 43 \\
\hline 4 & FAHRI ANA LATIFAH & 49 \\
\hline 5 & VIRA NUR'AINI & 44 \\
\hline 6 & ROOSTAFA EKA NUR S & 34 \\
\hline 7 & WINDA RAHAYUNINGTIYAS & 44 \\
\hline 8 & WAHYU CIPTANINGTYAS & 39 \\
\hline 9 & CINDY ERIA LUBIS & 50 \\
\hline 10 & YUNI ELLYAS ASMARA & 55 \\
\hline 11 & ALFIAN EKA PERWIN & 47 \\
\hline 12 & VALENTINA ROSSI WIBOWO & 43 \\
\hline 13 & SEPTIANA ROFIKA SARI & 42 \\
\hline 14 & DYAH AYU RETNO PALUPI & 36 \\
\hline 15 & INA MURNI RAHAYU & 44 \\
\hline 16 & KARISNA FITRIAWATI & 38 \\
\hline 17 & SITI NUR KHOFIFA & 44 \\
\hline 18 & SHEILLA OCTAVIRA PUTRI P & 53 \\
\hline 19 & SHERINA AGUSTIN & 40 \\
\hline 20 & MUNIKA SEPTI PERMATASARI & 44 \\
\hline
\end{tabular}

Berdasarkan Tabel 6 terlihat bahwa skor rata-rata respon mahasiswa terhadap penggunaan media E-learning menggunakan portal pembelajaran mahasiswa pada mata kuliah konsep dasar IPA 2 di era disruption adalah sebesar 44 atau 80\%. Hal ini berarti bahwa tingkat kepraktisan media tersebut berdasarkan respon mahasiswa mencapai $80 \%$ dengan kategori sangat praktis.

\section{Hasil Uji Keefetivan Produk}

Keefektifan media E-learning menggunakan portal pembelajaran mahasiswa pada mata kuliah konsep dasar IPA 2 di era disruption diperoleh dari hasil belajar mahasiswa dengan mengerjakan soal evaluasi yang ada di dalam media E-learning dalam bentuk menu soal evaluasi. Soal ini dikerjakan setelah selesai kegiatan pembelajaran menggunakan media E-learning, mahasiswa mengerjakan dengan durasi waktu yang 
Kharisma, Susi, Pengembangan E-learning Menggunakan Portal...

sudah dikerjakan, kemudian hasil penilaian bisa langsung diketahui mahasiswa saat selesai pengerjaan, setelah tau nilai yang diperoleh kemudian mahasiswa bisa melihat pembahasan soal. Soal evaluasi berisi soal-soal yang berkaitan dengan mata kuliah konsep dasar IPA 2 di era disruption pada materi Tubuh Manusia (Rangka, Sendi, dan Jenis Penyakit Tulang). Adapun data hasil belajar mahasiswa menggunakan media $E$ learning menggunakan portal pembelajaran mahasiswa pada mata kuliah konsep dasar IPA 2 di era disruption adalah sebagaimana Tabel 7.

Tabel 7. Data Hasil Keefektifan

\begin{tabular}{|c|c|c|c|}
\hline No & Nama Mahasiswa & Nilai & Keterangan \\
\hline 1 & DWI NOVIA RACHMAWATI & 100 & Tuntas \\
\hline 2 & YULIANA NOVITASARI & 100 & Tuntas \\
\hline 3 & BELLA MEGA SANTOSO PUTRI & 94 & Tuntas \\
\hline 4 & FAHRI ANA LATIFAH & 94 & Tuntas \\
\hline 5 & VIRA NUR'AINI & 100 & Tuntas \\
\hline 6 & ROOSTAFA EKA NUR S & 87 & Tuntas \\
\hline 7 & WINDA RAHAYUNINGTIYAS & 100 & Tuntas \\
\hline 8 & WAHYU CIPTANINGTYAS & 87 & Tuntas \\
\hline 9 & CINDY ERIA LUBIS & 81 & Tuntas \\
\hline 10 & YUNI ELLYAS ASMARA & 100 & Tuntas \\
\hline 11 & ALFIAN EKA PERWIN & 87 & Tuntas \\
\hline 12 & VALENTINA ROSSI WIBOWO & 74 & Tidak Tuntas \\
\hline 13 & SEPTIANA ROFIKA SARI & 74 & Tidak Tuntas \\
\hline 14 & DYAH AYU RETNO PALUPI & 81 & Tuntas \\
\hline 15 & INA MURNI RAHAYU & 94 & Tuntas \\
\hline 16 & KARISNA FITRIAWATI & 81 & Tuntas \\
\hline 17 & SITI NUR KHOFIFA & 81 & Tuntas \\
\hline 18 & SHEILLA OCTAVIRA PUTRI P & 94 & Tuntas \\
\hline 19 & SHERINA AGUSTIN & 74 & Tidak Tuntas \\
\hline 20 & MUNIKA SEPTI PERMATASARI & 67 & Tidak Tuntas \\
\hline & Rata-rata & 87 & \\
\hline \multicolumn{3}{|c|}{ Mahasiswa yang tuntas } & 16 \\
\hline \multicolumn{3}{|c|}{ Mahasiswa yang tidak tuntas } & 4 \\
\hline
\end{tabular}

Tabel 7 menunjukkan bahwa rata-rata hasil belajar mahasiswa sebesar 87 dengan jumlah yang tuntas sebanyak 16 mahasiswa dan mahasiswa yang belum tuntas sebanyak 4 mahasiswa. Hal ini berarti bahwa prosentase ketuntasan hasil belajar mahasiswa mencapai $80 \%$ dengan kategori sangat efektif. Keefektiffan media E-learning menggunakan portal pembelajaran mahasiswa pada mata kuliah konsep dasar IPA 2 di era disruption sudah mencapai di atas kriteria ketuntasan minimum (KKM). KKM yang ditentukan untuk siswa yaitu 75 untuk setiap induvidu dan ketuntasan klasikal adalah 
Kharisma, Susi, Pengembangan E-learning Menggunakan Portal...

75\%. Berdasarkan hasil analisis data hasil belajar, media E-learning yang dikembangkan efektif untuk digunakan.

\section{PEMBAHASAN}

Dalam penelitian dan pengembangan ini menghasilkan sebuah produk media $E$ learning menggunakan portal pembelajaran mahasiswa pada mata kuliah konsep dasar IPA 2 di era disruption. Produk media dapat diakses di laman kharismahasyim.web.id . Setiap mahasiswa akan memperoleh akun sehingga dapat masuk dengan menggunakan username dan password yng sudah diberikan oleh dosen. Akun ini bersifat pribadi tetapi dapat seling terhubung baik dengan dosen maupun mahasiswa. Kapan pun dan dimanapun mahasiswa dapat mengakses akun ini sehingga mahasiswa dapat belajar dan melakukan pembelajaran tanpa terbatas oleh ruang dan waktu, sehingga dengan adanya media E-learning sebenarnya perkuliahan dapat dilakukan tanpa bertatap muka di dalam kelas. Hal ini sesuai dengan pendapat (Daryanto, 2013) bawa media diartikan sebagai pengantar atau perantara, yang berarti media sebagai pengantar pesan dari pengirim (komunikator) kepada penerima (komunikan). Dalam dunia pendidikan dan pembelajaran, pun demikian bahwa media diartikan sebagai alat dan bahan yang membawa informasi atau bahan pelajaran yang bertujuan mempermudah mencapai tujuan pembelajaran.

Berdasarkan hasil analisis validitas produk dalam penggunaan media E-learning menggunakan portal pembelajaran mahasiswa pada mata kuliah konsep dasar IPA 2 di era disruption yang ditinjau dari validasi ahli materi, validasi ahli vamedia, dan validasi ahli bahasa dapat diperoleh bahwa analisis validasi dari ahli materi diperoleh hasil $88 \%$ dengan kategori valid dan tanpa revisi. Untuk analisis validitas dari ahli media diperoleh hasil 89\% dengan kategori valid dan tanpa revisi. Sedangkan untuk analisis validitas dari ahli bahasa diperoleh hasil $86 \%$ dengan kategori valid dengan sedikit revisi. Perlu sdikit revisi dari aspek bahasa yaitu validator memberikan saran agar kata dan kalimat yang digunakan dalam sistem E-learning harus mengacu pada aturan dan kaidah bahasa Indonesia yang baik dan benar. Berdasarkan hasil analisis data dari ketiga validator yaitu ahli materi, ahli media, dan ahli bahasa dapat dinyatakan bahwa media E-learning menggunakan portal pembelajaran mahasiswa pada mata kuliah konsep dasar IPA 2 di era disruption valid untuk digunakan dalam pembelajaran mahasiswa PGSD yang 
Kharisma, Susi, Pengembangan E-learning Menggunakan Portal... menempuh mata kuliah konsep dasar IPA 2 di era disruption. Hal ini didukung oleh pendapat (Sujana, 2005) bahwa E-learning mempunyai kelebihan yaitu memberikan fleksibilitas, interaktivitas, kecepatan, visualisasi melalui berbagai kelebihan dari masingmasing media.

Produk ini dikatakan praktis berdasarkan hasil uji coba lapang berdasarkan respon pengguna dan mahasiswa yang menempuh mata kuliah konsep dasar IPA 2 di era disruption. Dari hasil respon mahasiswa saat uji coba terbatas didapatkan hasil rata-rata sebesar $80 \%$ dan tahap uji coba lapangan skor kepraktisan dari 20 mahasiswa yaitu $80 \%$ dengan kategori sangat praktis. Sedangkan berdasarkan respon pengguna mendapatkan hasil sebesar 90\% dengan kategori sangat praktis, dalam hal ini praktis berarti mudah untuk digunakan bagi pengguna atau dosen dan mahasiswa. Hal ini sesuai dengan (Nieveen, 2010) menyatakan bahwa produk yang dikembangkan dikatakan praktis jika pengguna (dosen dan mahasiswa) menyatakan produk mudah digunakan.

Produk media E-learning menggunakan portal pembelajaran mahasiswa pada mata kuliah konsep dasar IPA 2 di era disruption yang telah dikembangkan ini juga dinyatakan efektif karna memberikan dampak yang positif terhadap hasil belajar mahasiswa. Keefektifan produk tersebut dibuktikan dengan prosentase ketuntasan hasil belajar mahasiswa yang mencapai $80 \%$ dengan kategori sangat efektif. Keefektiffan media $E$ learning sudah mencapai diatas kriteria ketuntasan minimum (KKM). Berdasarkan data analisis keefektiffan mahasiswa diketahui dari 20 mahasiswa 16 mahasiswa telah memperoleh nilai diatas KKM yang telah ditentukan. KKM yang ditentukan untuk mahasiswa yaitu 75 untuk setiap induvidu dan ketuntasan klasikal adalah 75\%. Hal ini senada dengan hasil penelitian eksperimen yang dilakukan oleh (Surjono \& Nurkhamid, 2008) dalam penelitian tersebut menunjukkan bahwa hasil belajar mahasiswa yang melakukan kegiatan perkuliahan dengan menggunakan E-learning adaptif jauh lebih maksimal dari hasil belajar mahsiswa yang tidak menggunakan E-learning non-adaptif. (Triantafillou, et.al 2004) melakukan penelitian eksperimen untuk melakukan evaluasi mengenai efektivitas sistem E-learning AES-CS. Hasil yang diperoleh menunjukkan bahwa hasil belajar mahasiswa yang menggunakan sistem E-learning adaptif jauh lebih maksimal dari hasil belajar mahasiswa yang tidak menggunakan sistem E-learning nonadaptif. 
Kharisma, Susi, Pengembangan E-learning Menggunakan Portal...

\section{SIMPULAN}

Berdasarkan analisis hasil penelitian yang telah dikemukakan dapat disimpulkan: 1) Validitas produk media E-learning menggunakan portal pembelajaran mahasiswa pada mata kuliah konsep dasar IPA 2 di era disruption memenuhi kriteria valid berdasarakan ahli materi $88 \%$, ahli media $89 \%$, ahli bahasa $86 \%$, serta dapat digunakan dalam pembelajaran mahasiswa PGSD yang menempuh mata kuliah konsep dasar IPA 2. 2) Kepraktisan produk media E-learning menggunakan portal pembelajaran mahasiswa pada mata kuliah konsep dasar IPA 2 di era disruption berdasarkan respon mahasiswa mencapai $80 \%$ dan respon pengguna sebesar 90\%. 3) Keefektifan dilihat berdasarkan ketuntasan hasil belajar mahasiswa mencapai $80 \%$ dengan kategori sangat efektif. Keefektiffan media sudah mencapai diatas kriteria ketuntasan minimum (KKM). Berdasarkan data tersebut dapat disimpulkan bahwa media E-learning yang telah dikembangkan sudah terbukti valid, praktis, dan efektif. Sehingga media E-learning menggunakan portal pembelajaran mahasiswa pada mata kuliah konsep dasar IPA 2 di era disruption layak untuk digunakan. Sesuai dengan simpulan hasil penelitian, saran yang dapat diberikan adalah: 1) media E-learning menggunakan portal pembelajaran mahasiswa pada mata kuliah konsep dasar IPA 2 di era disruption dapat dijadikan salah satu alternatif dalam proses pembelajaran mahasiswa. 2) perguruan tinggi hendaknya mensosialisasikan media E-learning menggunakan portal pembelajaran mahasiswa pada mata kuliah konsep dasar IPA 2 kepada semua dosen.

\section{UCAPAN TERIMA KASIH}

Peneliti mengucapkan terima kasih kepada seluruh pihak yang telah membantu sehingga terselesaikan nya penelitian ini. Peneliti juga menyampaikan terimakasih kepada Universitas Nusantara PGRI Kediri yang telah memberi dukungan untuk kegiatan penelitian ini, serta pada khususnya kepada Direktorat Riset dan Pengabdian Mayarakat, Direktorat Jenderal Penguatan Riset dan Pengembangan Kementerian Riset, Teknologi, dan Pendidikan Tinggi yang telah mendukung penelitian ini melalui dana hibah Penelitian Dosen Pemula. 
Kharisma, Susi, Pengembangan E-learning Menggunakan Portal...

\section{DAFTAR RUJUKAN}

Borg, W. R. \& Gall, M.D. (1987). Educational Research. An Introduction (4th ed.). New York: Longman Inc.

Daryanto. (2013). Media Pembelajaran : Peranannya Sangat Penting Dalam Mencapai Tujuan Pembelajaran.Yogyakarta:Gava Media.

Kasali, Renald. 2017. Disruption. Jakarta: Gramedia Pustaka Utama.

Khan, Badrul. (2005). Managing E-learning: Design, Delivery, Implementation and Evaluation. Hershey, PA: Information Science Publishing.

Lee, W. W. \& Owens, D. L. (2004). Multimedia-Based Instructional Design. San Francisco: Pleiffer

Nieveen, N., Mc Kenney, S., \& Akker, J.V.D. (2006). Educational Design Research: The Value of Variety. Dalam Akker, J.V.D., Gravemeijer, K., McKenney, S., \& Nieveen, N (Eds.), Educational Design Research (hlm. 144-184). Enchede: Axis Media-ontwerpens.

Sujana, Janti Gristinawati dan Yuyu Yulia. 2005. Perkembangan di Indonesia. Bogor: IPB Press.

Surjono, H.D., \& Nurkhamid. (2008). Pengembangan Model E-learning Adapif terhadap Keragaman Gaya Belajar Mahasiswa untuk Meningkatkan Efektivitas Pembelajaran. Laporan Penelitian Hibah Bersaing. Universitas Negeri Yogyakarta.

Triantafillou, E., et al. (2004). "The Value Of Adaptivity Based On Cognitive Stiyw: An Empirical Study”. British Journal of Educational Technolpgy,35,(1), 95-106. 